\title{
Philonsorbonne
}

12 | 2018

Année 2017-2018

\section{Moral motivation and judgment in virtue ethics}

Rui SAMPAIO DA SILVA

\section{(2) OpenEdition}

\section{Journals}

\section{Electronic version}

URL: https://journals.openedition.org/philonsorbonne/993

DOI: 10.4000/philonsorbonne.993

ISSN: 2270-7336

\section{Publisher}

Publications de la Sorbonne

\section{Printed version}

Date of publication: 1 January 2018

Number of pages: 107-123

ISSN: 1255-183X

\section{Electronic reference}

Rui SAMPAIO DA SILVA, "Moral motivation and judgment in virtue ethics", Philonsorbonne [Online], 12

2018, Online since 19 March 2018, connection on 08 June 2021. URL: http://journals.openedition.org/ philonsorbonne/993; DOI: https://doi.org/10.4000/philonsorbonne.993

\section{(c) Tous droits réservés}




\title{
Moral motivation and judgment in virtue ethics
}

\author{
Rui SAMPAIO DA SILVA \\ (University of the Azores, Portugal) \\ (Labcom.IFP - University of Beira Interior, Portugal)
}

Contemporary normative ethics is dominated by three movements: deontological ethics, with a focus on duties or obligations; consequentialism, with a distinctive emphasis on the outcomes of actions; and virtue ethics, which is centred on the moral agent. Because it rejects rule-based accounts of ethics (like consequentialism and deontological ethics), virtue ethics dedicates special attention to our capacity for moral judgment, understood as a practical capacity that cannot be reduced to propositional knowledge. In this article, I will analyse the nature of moral motivation (1) and the idea of moral perception in virtue ethics (2), the structure of moral judgment (3), its relation to rules or principles (4) and, finally, the conditions of its reliability (5).

\section{Moral motivation in virtue ethics}

The agent's motivation does not play a particularly important role in consequentialist ethics, because moral decisions are based on an impersonal and objective evaluation of the consequences of actions. On the other hand, Kant's moral philosophy, the example par excellence of a deontological ethics, is characterized by an austere, restrictive account of moral motivation; it recognizes a fundamental motive, respect for the moral law, but it denies the moral value of other motivational factors, which are generically grouped under the concept of inclination (Neigung). Virtue ethics, on the contrary, not only recognizes the importance of the motives of action, but also offers a rich account of moral motivation; thoughts, desires 
or feelings have motivational force and play a crucial role in the moral evaluation of actions. One can even attribute a motivational pluralism to virtue ethics; according to Valerie Tiberius, there are as many motivations as there are virtues. ${ }^{1}$

Virtue ethics may be considered an ethics of harmony, in the sense that it tries to reconcile our affective and emotional life with the rational side of human nature. In opposition to what Stocker called "the schizophrenia of modern moral theories", virtue ethics avoids a gap between the motives and the reasons of an agent. In his words: "we should be moved by our major values, and we should value what our major motives seek. (...) [S] uch harmony is a mark of a good life".

Aristotle, the main historical advocate of virtue ethics, conceived of virtue as a disposition to act, a perceptual capacity and a power to regulate emotions. However, he was not totally clear on the exact nature of the relation between reason and desire, ${ }^{3}$ and this indeterminacy leads to a conflict of interpretations, with "Humean" or "quasi-Humean" interpreters arguing that human action has its source in desires, not in reason, whereas their opponents emphasize the role of reason and cognitive states in moral motivation.

On behalf of the "Humean" interpretation, it is usual to quote those passages (sometimes called the "Goal passages") where Aristotle stresses that the goals of our actions are given by moral virtues and that moral deliberation only reflects on the means leading to those ends. ${ }^{4}$ In fact, these passages do not constitute decisive evidence for a Humean interpretation of Aristotle, since it is plausible to argue that deliberation, despite departing from previously given ends, plays a crucial role in the contextual determination of these ends; virtue supplies our ends, determinable ends, but deliberation and practical wisdom (phronêsis) make them determinate. ${ }^{5}$

1. V. Tiberius, Moral Psychology, London/New York, Routledge, p. 108.

2. M. Stocker, "The schizophrenia of modern moral theories", in Virtue Ethics, R. Crisp and M. Slote (eds.), Oxford, Oxford University Press, 1997, p. 66.

3. For instance, in a passage on the distinction between the rational and irrational parts of the soul, Aristotle dismisses, as not relevant for his purposes, the question of whether they are really separate or whether they are "distinct by definition, but by nature inseparable, like convex and concave in the circumference of a circle" (Nicomachean Ethics, 1102a26-32). The translations from Aristotle follow this publication: The Complete Works of Aristotle: The revised Oxford translation, edited by Jonathan Barnes, Princeton, Princeton University Press. 1984.

4. See, for example, Aristotle, Nicomachean Ethics, 1144a7-9: "excellence [aretê] makes the aim right, and practical wisdom [phronêsis] the things leading to it."

5. We can distinguish, with John McDowell, between two different accounts of deliberation that recognize the specificatory (and not merely instrumental) role of practical reasoning: one that conceives of practical thought as "shaping part of the general content of a conception of the end", and another that conceives of it as "discerning what an already held conception of the end requires of one in a given predicament" (J. McDowell, Mind, Value, and Reality, Cambridge, MA, Harvard University Press, 1998, p. 32). McDowell endorses the latter account. 
This "specificationist" view of practical reason clearly differs from the instrumentalist account that is traditionally attributed to Hume. Moreover, far from conceiving of reason as "the slave of the passions", Aristotle claims that the non-rational part of the soul obeys the rational part. ${ }^{6}$ The Aristotelian distinction between passion and reason does not entail that passions are deprived of reason or that reason lacks motivating power. As Rosalind Hursthouse claims, in her defence of virtue ethics and in her interpretation of Aristotle, emotions are Janus-faced: "animal and/or non-rational one face; rational the other". In contrast with the Humean thesis that there is only one principle of action (passion or desire), Aristotle claims that in the case of the human being there are two principles of action which do not always agree. $^{8}$ In a similar vein, Aristotle contrasts desire or appetite (epithumia) with choice (prohairesis), which is conceived of as a "deliberate desire [bouleutikê orexis] of things in our own power". His distinction between the continent (enkratês) and incontinent (akratês) person is also based on this contrast: the "incontinent man acts with appetite, but not with choice; while the continent man on the contrary acts with choice, but not with appetite". 9

It is true that Aristotle says that practical wisdom depends on ethical virtues, but the opposite is also true. On the one hand, ethical virtue requires reason, because virtues are dispositions "concerned with choice, lying in a mean relative to us, this being determined by reason $[\log o s]$ and in the way in which the man of practical wisdom would determine it". ${ }^{10}$ On the other hand, virtue co-operates with a "right reason" (orthos logos) provided by phronêsis, and for this reason there are no ethical virtues without practical wisdom. ${ }^{11}$ Equally significant is the Aristotelian distinction between natural virtue, as displayed by children, for instance, and virtue in a proper sense, which requires thought. ${ }^{12}$

A purely "Humean" interpretation seems to be simply wrong, but there are moderate or "quasi-Humean" interpretations. A case in point is Jessica Moss, but her attempt to offer a "modified" Humean interpretation is vulnerable to at least two objections. Firstly, she accepts that Aristotelian deliberation cannot be reduced to instrumental reasoning or means-ends calculations: "deliberation is a process of making an indeterminate end

6. Aristotle, Nicomachean Ethics, 1102b25-1103a5.

7. R. Hursthouse, On Virtue Ethics, Oxford, Oxford University Press, 1999, p. 110.

8. The following passage from the Eudemian Ethics clearly shows this fundamental difference between Aristotle and Hume: "And so with the other animals the action on compulsion is simple (just as in the inanimate), for they have not desire [orexis] and reason [logos] opposing one another, but live by desire; but man has both" (Aristotle, Eudemian Ethics, 1224a25-30; cf. Hursthouse, op. cit., p. 102-103).

9. Cf. Aristotle, Nicomachean Ethics, 1113a11 and 1111b14-15.

10. Ibid., 1106b36-1107a2.

11. Cf. ibid., 1144b20-31.

12. Cf. ibid., 1144b1-14. 
sufficiently determinate to be acted upon". ${ }^{13}$ However, this is a very substantial concession from a Humean standpoint, which makes the label "quasi-Humean" dubious. Secondly, she tries to downplay the role of reason in moral education, making the strong claim that the content of our ends "is dictated entirely by one's nonrational upbringing and character", ${ }^{14}$ but this is not a charitable interpretation of Aristotle; it is very difficult to reconcile this claim with the observation of ordinary processes of moral upbringing, which often involve justifications or the presentation of reasons. ${ }^{5}$ In sum, even "modified", "Humean" interpretations of Aristotle are not convincing.

At any rate, my main intention is not exegetical, but philosophical, and in what follows I will propose an account of virtue ethics, inspired by Aristotle, that rejects the modern dichotomy between cognition and volition. If we accept, as we should, that the cultivation of virtues is not a mere process of moral conditioning, but involves (paraphrasing a well-known phrase from Sellars) "the game of giving and asking for reasons", we arrive naturally at a conception of virtue as a disposition that inextricably combines cognitive and volitional or conative factors. It is precisely because moral education and habituation are not a blind, nonrational, unreflective process that desires, as moulded inclinations, far from being brute causal forces, have a rational character. As Norman Dahl put it, in his interpretation of Aristotle: "Mind [nous] is a source of action because it contributes to the desires that move people to act"16.

\section{Moral perception}

The idea of moral perception provides another important reason to reject the cognitive/volitional dichotomy. According to a Humean

13. J. Moss, "Was Aristotle a Humean", in The Cambridge Companion to Aristotle's Nicomachean Ethics, R. Polansky (ed.), Cambridge, Cambridge University Press, 2014, p. 238. Moss endorses, in this context, the interpretation of the Aristotelian deliberation proposed by Daniel Russell, who claims, in particular, that "deliberating about 'things that are conducive to ends' includes thinking about not only means to an end but also the very specification of that end in more concrete terms" (D. Russell, "Phronesis and the Virtues", in The Cambridge Companion to Aristotle's Nicomachean Ethics, R. Polansky, Cambridge, Cambridge University Press, 2014, p. 205.

14. J. Moss, op. cit., p. 234.

15. In the words of Daniel Russell: "For Aristotle, training in virtue is simultaneously a blend of rational and non-rational training: and in fact, that simultaneous blend seems to be what we actually observe" ("Aristotle on Cultivating Virtue", in Cultivating Virtue: Perspectives from Psychology, Theology, and Psychology, N. Snow (ed.), Oxford, Oxford University Press, 2015, p. 26. For a well-argued interpretation of Aristotelian habituation as a reflective and critical process, see N. Sherman, The Fabric of Character: Aristotle's theory of virtue, Oxford, Clarendon, 1989, ch. 5.

16. N. Dahl, "Aristotle on Action, Practical Reason, and Weakness of the Will", The Blackwell Companion to Aristotle, in G. Anagnostopoulos (ed.), Oxford, Blackwell, 2009, p. 498. 
perspective, the world is constituted by "morally inert facts", ${ }^{17}$ and moral evaluations have their source in our feelings. Since there is not a moral reality, the very notion of moral perception could be considered a category mistake. Things are different in virtue ethics, because it is possible to show how life experience and the cultivation of virtues affect our perception of the world. On the one hand, the moral upbringing and education of virtuous agents is a process whereby they obtain knowledge of many relevant situations and, consequently, an interpretive framework that will shape the perception of future, similar situations. On the other hand, the intellectual virtue of phronêsis, practical wisdom, also benefits from the virtuous agent's experience, enabling her or him to identify the morally relevant aspects of a situation. It is related to capacities like sunesis ("understanding" or "comprehension") and gnômê ("judgment" or "discernment"), which are discriminatory abilities. The former contributes to reading the relevant details of a situation one is in by considering the perspectives of other agents. In the words of Rosalind Hursthouse, sunesis "involves judging what other people say, particularly about their own, or someone else's, actions and/or feelings". "Gnomê, in turn, is briefly defined by Aristotle as "the right discrimination of equitable". ${ }^{19} \mathrm{He}$ adds that the equitable man is a "man of forgiveness", but an adequate understanding of gnômê must take also into consideration the analysis of the virtue of equity at the end of Book V of the Nicomachean Ethics, where it is presented as the capacity to correct general laws in the presence of exceptional cases. Generalizations in the ethical domain hold only in most cases, and for this reason practical wisdom requires a special sensitivity to exceptional or atypical cases. According to Daniel Russell, phronêsis and the aforementioned discriminatory capacities "extract relevant information from one's surroundings that might well be lost on others" ${ }^{20}$ The use of the expression "relevant information" is particularly significant in this context, because it shows the entanglement of cognitive and evaluative factors in moral perception; information is a cognitive notion, but relevance depends on evaluative judgments.

Understood in these terms, there is nothing mysterious in the idea of moral perception; like perception in general, moral perception is based on pattern-recognition, ${ }^{21}$ with the difference that the corresponding patterns are not merely physical, because they can only be grasped by someone with the

17. N. Athanassoulis, Virtue Ethics, London/New York, Bloomsbury, 2013, p. 74.

18. R. Hursthouse, "Practical wisdom: A mundane account", Proceedings of the Aristotelian Society, 106, (2006), p. 293. She also claims that the perceptual model of practical wisdom leads to "the neglect of the others" (ibid., p. 287), but advocates of this model (like Wiggins or McDowell) can, and should, incorporate the perspectives of other agents in the notion of moral perception.

19. Aristotle, Nicomachean Ethics, 1143a20.

20. D. Russell, "Aristotle on Cultivating Virtue", in Cultivating Virtue: Perspectives from Psychology, Theology, and Psychology, N. Snow (ed.) Oxford, Oxford University Press, 2015 , p. 25.

21. Cf. T. Chappell, “Moral Perception”, Philosophy, 83, (2008), p. 421-437. 
required moral education and experience. Since access to reality is mediated by perceptual and discriminatory capacities, whose development involves a mix of cognitive, emotional and conative factors, moral agents do interact with a value-laden reality. With the collapse of the cognitive/volitional dichotomy, the fact/value dichotomy also falls apart.

Far from being a passive appreciation of the morally relevant aspects of reality, moral perception is, in the case of the virtuous agents, intrinsically motivating; it is a "desire-infused perception". 22 If they perceive that a particular situation might be humiliating for someone, they would act in order to avoid humiliation; if they perceive that someone needs help, this perception immediately motivates them to help. Quoting Margaret Little: "There are certain ways of seeing or of conceiving the world, as many have put it, that one cannot have without reacting affectively in a certain way". ${ }^{23}$

McDowell's defence of moral perception is particularly relevant in this context, not only because of his illuminating analysis of the notion, but also because he integrates moral perception into a broader epistemological framework. In fact, McDowell endorses a "naturalism of the second nature" or an "Aristotelian naturalism", according to which our access to reality is mediated by a conceptual web and a space of reasons, into which an individual is initiated through the development of human conceptual capacities in a process that is simultaneously natural and cultural. Moral education is one of the dimensions of this initiation into a "space of reasons". ${ }^{24}$ Against the "disenchanted nature" of the modern science, the "naturalism of the second nature" leads to a "partial re-enchantment of nature", ${ }^{25}$ in the sense that nature reveals itself as already being infused with meaning and value.

The notion of moral perception arises naturally in this epistemological framework. Virtue as a perceptual capacity is a form of knowledge; "The deliverances of a reliable sensitivity are cases of knowledge". ${ }^{26}$ Moral perception is characterized by a grasp of the morally relevant aspects of a situation:

22. C. Reeve, "Aristotle on the Virtues of Thought", The Blackwell Companion to Aristotle's Nicomachean Ethics, in R. Kraut, Oxford, Blackwell, 2006, p. 209.

23. M. Little, "Virtue as Knowledge: Objections from the Philosophy of Mind", Noûs, 3, (1997), p. 71.

24. "Moulding ethical character (...) is a particular case of a general phenomenon: initiation into conceptual capacities which include responsiveness to other rational demands besides those of ethics" (J. McDowell, Mind and World, Cambridge, MA, Harvard University Press, 1996 [1994], p. 84). In a similar vein, John McDowell also claims that the topic of Book II of the Nicomachean Ethics is "initiation into a conceptual space" (J. McDowell, Mind, Value, and Reality, Cambridge, MA, Harvard University Press, p. 39).

25. J. McDowell, Mind and World, Cambridge, MA, Harvard University Press, 1996 [1994], p. 88.

26. J. McDowell, Mind, Value, and Reality, Cambridge, MA, Harvard University Press, 1998, p. 51 . 
It is by virtue of his seeing this particular fact rather than that one as the salient fact about the situation that he is moved to act by this concern rather than that one. This perception of saliences is the shape taken here by the appreciation of particular cases. ${ }^{27}$

On the one hand, and to the extent that virtues are closely related to desires and dispositions to act, virtues have a volitional character; on the other hand, and taken as a perception of the morally relevant aspects of a situation, they have a cognitive character too. In this sense, virtue ethics can be considered a form of moral cognitivism. There is moral knowledge, and cognitive states like perceptions can motivate our actions. The development of this position can take two forms: to posit the existence of sui generis mental states that are simultaneously cognitive and volitional (with a double "direction of fit" ${ }^{28}$ ) or, alternatively, to claim more modestly that certain beliefs or perceptions are accompanied by certain reactions or desires.

\section{The nature of moral judgment}

The rejection of the cognitive/volitional dichotomy entails a rejection of the so-called "Humean theory of motivation", the view that "motivation has its source in the presence of a relevant desire and a means-end belief". ${ }^{29} \mathrm{We}$ can again follow John McDowell, now in his interpretation of practical syllogism, in order to clarify this point. He opposes the tendency to decompose such a syllogism in two distinct and heterogeneous components: a volitional and non-cognitive state (present in the major premise) and a belief (present in the minor premise), understood as a cognitive state deprived of motivating power. The notion of moral perception undermines such a decomposition. The concerns that motivate an agent cannot be considered as independent of her perception of the situation. Again quoting Margaret Little, someone who considers virtue a form of knowledge may well claim that "all motivational failures do involve a cognitive failure, for the simple reason that, since the virtuous person's ideal conception of a situation guarantees proper motivation, any who are not moved cannot be enjoying that conception". ${ }^{30}$ However, this is not exactly McDowell's view, because he recommends a "a less extreme possibility" suggested by Aristotle:

27. Ibid., p. 68.

28. Beliefs have a mind-to-world direction of fit, whereas desires have a world-to-mind direction (see, for example, M. Smith, "The Humean Theory of Motivation", Mind, 96, (1987), p. 36-61.

29. M. Smith, op. cit., p. 36.

30. M. Little, op. cit., p. 72. 
to allow that someone who fails to act virtuously may, in a way, perceive what a virtuous person would, so that his failure to do the right thing is not inadvertent; but to insist that his failure occurs only because his appreciation of what he perceives is clouded, or unfocused, by the impact of the desire to do otherwise. This preserves the identification of virtue with a sensitivity. ${ }^{31}$

Here, the fundamental factor is the "deliverances of the sensitivity", which can be available to both the virtuous and non-virtuous person, but in the latter there is some deficiency in the approach to the situation. Using metaphorical terms ("clouded", "unfocused"), McDowell attempts to strike a difficult balance between the thesis that moral knowledge moves us to act and the thesis that the virtuous and the non-virtuous person can have the same cognitive access to a situation.

The centrality of moral perception in this account of virtue ethics has important implications at the level of moral judgment. The idea of moral perception seems to be incompatible with an account of moral judgment as the result of a weighing of different reasons, and this consequence is clearly accepted by McDowell:

The distinction [between the virtuous and continent person] becomes intelligible if we stop assuming that the virtuous person's judgment is a result of balancing reasons for or against. The view of a situation that he arrives at by exercising his sensitivity is one in which some aspect of the situation is seen as constituting a reason for acting in some way; this reason is apprehended, not as outweighing or overriding any reasons for acting in other ways (...), but as silencing them. ${ }^{32}$

McDowell qualifies as "incredible" the view that virtuous actions are the result of reasoning, but how can we reconcile this claim with the Aristotelian emphasis on the role of deliberation in moral judging? He tries to remain faithful to his Aristotelian inspiration by interpreting "Aristotle's discussion of deliberation as aimed at the reconstruction of reasons for actions not necessarily thought out in advance". ${ }^{33}$ It seems, however, that there is no real problem in recognizing the importance of both moral perception and deliberation in moral judging. An analogy with chess can clarify this point. Chess masters often, and successfully, rely on intuition, which is usually defined in the field of psychology of expertise as patternrecognition. But when they are confronted with unfamiliar and complex situations they can no longer rely solely on intuition and have to delve into complex calculations. Thinking and decision-making processes in chess require a permanent oscillation between intuition and calculation. One can admit, with McDowell, that moral judgment is usually spontaneous

31. J. McDowell, Mind, Value, and Reality, Cambridge, MA, Harvard University Press, 1998, p. 54 .

32. Ibid., p. 55-56.

33. Ibid., p. 66, n. 22. 
in familiar situations that exhibit an already known pattern, but the phenomenology of moral judgment shows us that there are also non-familiar situations where we are confronted with new problems and hard cases to which we do not have an already formed answer. In this type of situation, different moral rules may enter into conflict and the moral judgment must weigh the reasons for or against a certain course of action. McDowell has the merit of offering a description of the habitual moral judgment of a virtuous agent, but in doing so he neglects this second, reflective form of moral judgment.

\section{Rules and moral judgment}

Virtue ethics is opposed to any type of "one-size-fits-all decision procedure" ${ }^{34}$ and is often combined with to the so-called Uncodifiability Thesis: the view that moral knowledge cannot be codified in a set of rules or principles. ${ }^{35}$ Rule-based accounts of ethics face, indeed, two fundamental problems. Firstly, there is a gap between general principles and the unpredictable diversity of situations that demand moral decisions; as a result, it is often very difficult to determine how to apply a principle to atypical, unfamiliar situations. It is even possible to arrive at different conclusions departing from the same principle. Secondly, as the existence of moral dilemmas demonstrates, there can be clashes between equally valuable principles, depriving thereby the agent of action guidance. The problem becomes even more complicated when we take into consideration the nuanced character of the moral judgment in virtue ethics, where it is not enough to judge in general terms whether an action is right; one must also be sensitive to the contextual, sometimes unique details of a situation, which cannot be anticipated by general rules. As Aristotle said, a virtuous person knows how to feel or act towards "the right person, to the right extent, at the right time, with the right aim, and in the right way". And he adds: "that is not for every one, nor is it easy"...

34. J. Annas, Intelligent Virtue, Oxford, Oxford University Press, 2011, p. 164.

35. McDowell's "Virtue and Reason" is an exemplary defence of the Uncodifiability Thesis. Its target is the idea that "the virtuous person's views about how, in general, one should behave are susceptible of codification, in principles apt for serving as major premises in [practical] syllogisms" (J. McDowell, Mind, Value, and Reality, Cambridge, MA, Harvard University Press, 1998, p. 57).

36. Aristotle, Nichomachean Ethics, 1109a26-9. Daniel Russell illustrates the fine-grained moral evaluations that are typical of virtue ethics with the example of generosity: "Sometimes helping means giving a little, sometimes it means giving a lot; sometimes it means giving money, sometimes it means giving time, or just a sympathetic ear; sometimes it means offering advice, sometimes it means minding one's own business; and which of these it might mean in this case will depend on such different things as my relationship with my friend, what I am actually able to offer, why and how often my friend has problems of this kind, and so on" ("Aristotle on Cultivating Virtue", in N. Snow (ed.), Cultivating Virtue: Perspectives from Psychology, Theology, and Psychology, Oxford, Oxford UP, 2015, p. 37-38). 
The Uncodifiability Thesis can be given a weak or a strong formulation. According to the weak formulation, rules or principles are insufficient to guide human action, according to the strong one, they are irrelevant. Aristotle, the main advocate of virtue ethics in the history of philosophy, endorses the former, more moderate version, which could be called the Insufficiency Thesis. Ethical generalizations are possible, but they typically hold only for the most part and allow for exceptions. Rules like "we must for the most part return benefits" or "we must pay back a loan to a creditor" are generally true, but unusual circumstances may justify exceptions $;{ }^{37}$ in the case of debts, Aristotle remarks that if aa gift is "exceedingly noble or exceedingly necessary", a debtor might be justified in not paying what is owed. The already mentioned virtue of equity (epieikeia), understood as a corrective of the application of law, provides a good illustration of this point. Because laws are too generic to accommodate all the possible circumstances of their application, the administration of justice requires the ability to identify omissions and to correct them:

all law is universal but about some things it is not possible to make a universal statement which will be correct. (...) When the law speaks universally, then, and a case arises on it which is not covered by the universal statement, then it is right, when the legislator fails us and has erred by oversimplicity, to correct the omission. (...) And this is the nature of the equitable, a correction of law where it is defective owing to its universality. ${ }^{38}$

There is, in fact, an important analogy between legal reasoning and moral reasoning; in both cases the application of rules cannot be considered a mechanical act or a linear, deductive inference, but an act that requires sensitivity to relevant aspects of a case or situation that cannot be handled by decision procedures.

Because phronêsis or practical wisdom cannot be reduced to a knowledge of universal principles, Aristotle emphasizes that it requires two types of knowledge: knowledge of the universal and knowledge of particular facts: "Nor is practical reason concerned with universals only - it must also recognize the particulars; for it is practical, and practice [praxis] is concerned with particulars". ${ }^{39}$ He even suggests that, in the domain of action, knowledge of particulars might be more important.

At any rate, it would be inaccurate to interpret Aristotle as proposing a wholesale rejection of universal rules. Adultery, theft and murder, for instance, are intrinsically bad and always wrong, ${ }^{40}$ and in this sense the condemnation of such acts amounts to universal rules. This is not a challenge to the Uncodifiability Thesis, however, because such absolute prohibitions

37. Aristotle, Nicomachean Ethics, 1164b30-1165a5.

38. Ibid., 1137b13-27.

39. Ibid., 1141b14-16.

40. Ibid., 1107a10-14. 
have a very limited practical role as action-guiding rules in everyday life. On the other hand, if we accept, as proposed by Timothy Chappell ${ }^{41}$, that it is very difficult to separate moral rules from moral reasons, because the latter have a certain degree of generality, then virtue ethicists may recognize the existence of a broader type of rules, but in this weak sense they do not have the same degree of normative force that is usually associated with the rules of a moral code.

\section{The reliability of moral judgments in virtue ethics}

Critics of virtue ethics often complain that this type of normative ethics is unable to provide action guidance. In order to assess this criticism, let us consider the following "specification" of right action proposed by Rosalind Hursthouse: "An action is right iff it is what a virtuous agent would characteristically (i.e. acting in character) do in the circumstances". ${ }^{42}$ This formulation seems vacuous. Hursthouse argues that the consequentialist's appeal to "best consequences" and the deontologist's invocation of a "correct moral rule" is equally vague and in need of further specification, but this reply is a tu quoque argument that does not address the worry that virtue ethics might be irremediably vague and unable to provide action guidance. Hursthouse also claims that we can complement the proposed account of right action either by presenting a list of virtues or by giving a general definition of virtue, but even with these qualifications the proposal remains vague.

In the tradition of virtue ethics it is, in fact, common to stress the role of the virtuous agent as a guide for moral judgments and decisions. Aristotle, for instance, claimed that the virtuous person "differs from others most by seeing the truth in each class of things, being as it were the norm and measure of them". ${ }^{43}$ However, such an appeal to virtuous agents is problematic. They are, in fact, reliable guides, and one can even say that "virtuous acts track right actions", ${ }^{44}$ but it is relatively easy to make a list of relevant objections to the proposed equation of virtuous action and right action. ${ }^{45}$ For instance, how can we identify a virtuous agent? How can we imagine what an ideal virtuous agent would do in the circumstances? Even accepting that the set of right actions is co-extensive with the set of the moral actions of virtuous agents, the property of "being an action done by a virtuous agent" is unsatisfactory as a characterization of a right action, because it does not shed light on why an action is right.

41. Cf. T. Chappell, "Virtues and rules", in S. Hooft (ed.), The Handbook of Virtue Ethics, Durham, Acumen, 2014, p. 76-87.

42. R. Hursthouse, On Virtue Ethics, Oxford, Oxford University Press, 1999, p. 28.

43. Aristotle, Nicomachean Ethics, 1113a32-33.

44. H. Battaly, Virtue, Cambridge, Polity Press, 2015, p. 119.

45. Cf. N. Athanassoulis, op. cit., p. 68-69. 
In order to overcome these difficulties, one should complement the consideration of the actions of virtuous agents with an analysis of the conditions of their reliability as ethical models. Virtue ethicists frequently use the words "reliable", "reliability" and "reliably"; virtues are reliable dispositions to feel and to act, and virtuous agents are, accordingly, reliable in their judgments and decisions. The notion of moral reliability is, at first glance, obscure and mysterious, but it is possible to make it plausible as a key notion of virtue ethics. Aristotle already offered us important indications regarding the roots of the reliability of virtuous agents. He emphasized the role of a proper upbringing, ${ }^{46}$ of experience and of examples or models (like Pericles), but it is necessary to go beyond Aristotle to legitimize the idea of moral reliability.

Experience is, in fact, a fundamental precondition of the exercise of moral judgment because, as we have seen, rules and principles are insufficient. Experience provides us with a vast repertoire of particular situations and examples of good and bad decisions, and on the basis of this "knowledge of particular facts" the virtuous agent can spot similarities between a present situation and past ones. In other words, experience promotes pattern-recognition and the exercise of analogical reasoning, thereby helping to refine our capacity of judgment and our "perception of saliences".

The Hegelian and Gadamerian analysis of the negativity of experience helps us to understand and ground the ethical relevance of experience. According to Hegel's account of experience in The Phenomenology of Spirit, to make an experience is to become aware of the inadequacy of our conception of the objects; it involves a reversal of consciousness whereby we realize that things are not as we thought they were. Hans-Georg Gadamer, in his analysis of the hermeneutic experience, also stresses the negative character of experience; "experience is initially always experience of negation: something is not what we supposed it to be"; "every experience worthy of the name thwarts an expectation" ${ }^{47}$ Hermeneutic experiences transform their subject by correcting prejudices, or the inadequacy and limitations of one's pre-understanding of the world, and by offering a deeper knowledge of other people and cultures. Needless to say, the correction of prejudices and the openness to the alterity of the other significantly contributes to the development of our capacity of moral judgment.

Examples and models also develop, as we have seen, our capacity of moral judgment. Plutarch's Parallel Lives are an interesting example, because this series of biographies is also an Aristotle-inspired exercise in moral philosophy. The author of the Nicomachean Ethics stressed the importance of knowledge of particular facts to moral education, and

46. Aristotle claims that only those who "have been brought up in good habits" can benefit from the teachings of the Nicomachean Ethics (1095b5).

47. H.-G. Gadamer, Truth and Method, New York/London, Continuum, 2003, p. 354 and 356. 
Plutarch's biographies have a moral function precisely because they offer many particular cases of exemplary, virtuous actions (as well as wrong ones, which are also instructive). But Plutarch is not an isolated case; his motivation is typical in the humanist movement. The following presentation of the humanist educational ideal is, in this respect, very instructive:

Humanist educators aimed to create a particular type of person: men and women who would be virtuous because they had read and identified with powerful examples of classical virtue; who would be prudent because they had extended their human experience into the distant past through the study of history; and who would be eloquent, able to communicate virtue and prudence to others, because they had studied the most eloquent writers and speakers of the past. ${ }^{48}$

Here we see the deep connection between virtue ethics and the humanist tradition. Virtue ethics is the ethical theory most suited to humanism, and humanism offers an educational ideal that perfectly complements virtue ethics. One can plausibly claim that virtue ethics and humanistic education are two faces of the same coin.

There is a further element in the humanist tradition that can shed light on the Aristotelian claim that a proper upbringing contributes to the reliability of virtuous agents: reflection on the idea of Bildung in the German neo-humanist movement, developed by the likes of Humboldt, Herder, Goethe, Schiller, Hegel and, more recently, Gadamer. Bildung is a modern and liberal educational ideal. It has been presented, since its origins in the $18^{\text {th }}$ century, as a free and autonomous process of inner transformation that is characterized by a harmonious development of human beings in their affective, intellectual and moral dimensions. It involves, accordingly, knowledge of history, art, literature and philosophy. Also significant in the idea of Bildung is the insistence on the formative importance of experiences - both life experiences and the human experiences that are transmitted through a humanistic education.

Gadamer's conception of Bildung deserves a special reference in this context, because it is developed, in his opus magnum Truth and Method, in conjunction with an account of practical reason inspired by Aristotle, and one can legitimately interpret Gadamer's own account of practical reason as having its roots in a combination of the humanist idea of Bildung and the Aristotelian notion of phronêsis. The Gadamerian analysis of Bildung takes place in an epistemological framework that stresses the role of prejudices as ineliminable, yet partially controllable conditions of knowledge and understanding. As a result of the pervasive character of prejudices, understanding is not conceived of as a reconstruction of thoughts or mental

48. C. Kallendorf, "Introduction", in C. Kallendorf (ed.), Humanist Educational Treatises, Cambridge, MA, Harvard University Press, 2002, p. vii-viii. 
states but as a "fusion of horizons", a process in which the perspectives of the interpreter and the interpretandum interact, generating a new perspective on a particular subject. The important point to retain in this context is that genuine understanding typically transforms the interpreter by challenging their prejudices and broadening her view of the human reality. Gadamerian Bildung is an endless process of fusions of horizons, multiplication of hermeneutic experiences and correction of prejudices. The result is a refinement of our capacity of (moral) judgement; the gebildete person has a better understanding of other people, and because she has accumulated many experiences, she also has a rich knowledge of particular facts that Aristotle deemed as a key requirement of practical wisdom. There are, naturally, differences between the idea of Bildung and the Greek conception of paideia. Bildung, as a non-teleological process of self-determination that involves an openness to other cultures, is a modern educational idea, but this difference should be welcomed as an enrichment of virtue ethics.

One may object that even if the preceding considerations shed some light on how we can develop our capacity of moral judgment, there still remains a gap in the clarification of the notion of "proper upbringing", because it also involves a regulation of emotions and desires, and a mere appeal to the educational role of family and community is not satisfactory. Here, again, it is possible go beyond the vague formulations that are usual in the tradition of virtue ethics, by exploring a dialogue with psychology, especially with the psychology of emotions and the psychology of empathy. This is a large topic, which cannot be developed in the present article, but because of its relevance in this context I will briefly sketch its significance to virtue ethics.

Empathy, understood as the capacity to reconstitute or re-experience the mental states of other people, can be included in the family of skills associated with phronêsis; something like empathy is implicit in the aforementioned notion of sunesis. ${ }^{49}$ In fact, moral perception is clearly defective if the subject does not correctly grasp the mental states of the actors involved in a particular situation. It is important to stress that empathy is not a mere natural endowment, because it can be cultivated through different means. For instance, Martin Hoffman, who argues that empathy plays a fundamental role in the development of moral conscience, presents different forms of empathy induction. One important form consists of socializing processes that expose children to a diversified set of emotions, thereby increasing the scope of their empathic capacity. Another consists of giving affection to children, because children living in affective environments tend to be more attentive to the needs of others. The example of adults who express their sympathetic feelings towards people in need is also an effective means of developing empathy in the moral development of

49. Michael Slote is an example of a virtue ethicist who has dedicated special attention to an ethics of care and empathy (cf. M. Slote, The Ethics of Care and Empathy, London, Routledge, 2007). 
children. ${ }^{50}$ The fact that empathy, as a requirement of our exercise of moral judgment, can be explained and cultivated in a non-mysterious way helps to clarify the idea of moral reliability in virtue ethics.

The regulation of emotions, another important precondition of moral judgment according to virtue ethics, is also an important research topic involving psychology and philosophy. Kristján Kristjánsson offers a useful overview of the extensive psychological research on "tools and techniques" of emotion regulation. ${ }^{51}$ The author classifies them into three types of strategies: behavioural, conative and cognitive. The first type of strategies tries to regulate emotions by changing behaviour. One can, for instance, control certain emotions by avoiding the occasions that trigger them or by shifting the focus of one's attention. At a deeper level, conative strategies help regulate emotions by inducing modifications to desires and attitudes. Finally, cognitive strategies "involve a reframing or change in the cognitions that underlie our emotions" $"$. Such a classification relies on a "cognitive view of the emotions as potentially infused with reason and amenable to cultivation and coaching", 53 a view that has Aristotelian roots and is widely accepted in contemporary philosophy and psychology. The empiricallyminded Aristotle would certainly appreciate contemporary research on the education and regulation of emotions.

\section{Conclusion}

As I have tried to show, one major contribution by virtue ethics to normative ethics in general is its analysis of the capacity of moral judgment, qua practical capacity, and of the possibilities to develop and refine it. Even proponents of rule-based accounts of ethics have to recognize that sometimes moral agents struggle with hard cases or apparently irresolvable dilemmas, where the application of moral principles or rules is unclear, either due to difficulties in characterizing a situation, or due to the absence of compelling decision procedures and ranking rules (rules that establish a hierarchy of conflicting rules or principles). With its analysis of virtue as habituated dispositions to feel and act correctly, of moral perception, and of the role played by experience, examples and models in moral judging, virtue ethics shows how an agent can reliably judge a situation and act in the right way.

50. M. Hoffman, Empathy and Moral Development, Cambridge, Cambridge University Press, 2000, p. 288-289.

51. Cf. K. Kristjánsson, Aristotle, Emotions, and Education, Hampshire, Ashgate, 2007, p. 71-74.

52. Ibid., p. 73.

53. Ibid., p. 1. 
Since virtue ethics does not provide moral codes or algorithmic decision procedures, this idea of moral reliability plays a key role that demands an effort to provide clarification, without which the whole project of virtue ethics falters. However, the reliability of the virtuous agent is often more presupposed than explained, and for this reason I have tried to show that moral reliability, far from being an irredeemably vague and obscure notion, has clear sources and foundations, and can be developed in a non-mysterious way.

The centrality of virtue in moral philosophy is a fundamental tenet of virtue ethics that cannot be accepted by advocates of consequentialist or deontological approaches to ethics. However, a theory of virtues can be easily integrated into these approaches; a consequentialist might be sensitive to the fact that virtues are character traits that produce generally good effects or consequences and a deontologist philosopher may prize virtue to the extent that it promotes self-control and the moral strength that is necessary to act from duty. Considering that virtue ethics offers important insights regarding the nature of moral education and the refinement of our capacity of moral judgment, there are strong reasons to claim that a theory of virtues is not only compatible with other types of normative ethics, but should be part of them.

\section{References:}

ANNAS, J., Intelligent Virtue, Oxford, Oxford University Press, 2011.

ARIstotLe, Nicomachean Ethics, in The Complete Works of Aristotle, J. Barnes (ed.), vol. 2, Princeton, Princeton University Press, 1984.

ARISTOTLE, Eudemian Ethics, in The Complete Works of Aristotle, J. Barnes (ed.), vol. 2, Princeton, Princeton University Press, 1984.

Athanassoulis, N., Virtue Ethics, Bloomsbury, London/New York, 2013. Battaly, H., Virtue, Cambridge, Polity Press, 2015.

Chappell, T., "Moral Perception", Philosophy, 83, (2008), p. 421-437.

CHAPPELL, T., "Virtues and rules", in The Handbook of Virtue Ethics, S. Hooft (ed.), Durham, Acumen, 2014, p. 76-87.

DAHL, N., "Aristotle on Action, Practical Reason, and Weakness of the Will", in G. Anagnostopoulos (ed.), The Blackwell Companion to Aristotle, Oxford, Blackwell, 2009, p. 498-511.

Gadamer, H.-G., Truth and Method, New York/London, Continuum, 2003.

Hoffman, M., Empathy and Moral Development, Cambridge, Cambridge University Press, 2000.

Hursthouse, R., On Virtue Ethics, Oxford, Oxford University Press, 1999.

Hursthouse, R., "Practical wisdom: A mundane account", Proceedings of the Aristotelian Society, 106, (2006), p. 285-309. 
KALLENDORF, C., "Introduction", in Humanist Educational Treatises, C. Kallendorf (ed.), Cambridge, MA: Harvard University Press, 2002, p. vii-xvi.

KRISTJÁNSSON, K., Aristotle, Emotions, and Education, Hampshire, Ashgate, 2007.

LitTLE, M., "Virtue as Knowledge: Objections from the Philosophy of Mind", Noûs, 31, (1997), p. 59-79.

MCDowell, J., Mind and World, Cambridge, MA, Harvard University Press, 1996 [1994].

MCDowell, J., Mind, Value, and Reality, Cambridge, MA, Harvard University Press, 1998.

Moss, J., "Was Aristotle a Humean", in The Cambridge Companion to Aristotle's Nicomachean Ethics, R. Polansky, Cambridge, Cambridge University Press, 2014, p. 221-241.

REEVE, C., "Aristotle on the Virtues of Thought", in The Blackwell Companion to Aristotle's Nicomachean Ethics, R. Kraut, Oxford, Blackwell, 2006.

RUSSELl, D., "Phronesis and the Virtues", in The Cambridge Companion to Aristotle's Nicomachean Ethics, R. Polansky, Cambridge, Cambridge University Press, 2014, p. 203-220.

Russell, D., "Aristotle on Cultivating Virtue", in N. Snow (ed.), Cultivating Virtue: Perspectives from Psychology, Theology, and Psychology, Oxford, Oxford University Press, 2015, p. 17-48.

SHERMAN, N., The Fabric of Character: Aristotle's theory of virtue, Oxford, Clarendon, 1989.

SMitH, M., "The Humean Theory of Motivation", Mind, 96, (1987), p. 36-61.

SLOTE, M., The Ethics of Care and Empathy, London, Routledge, 2007.

STOCKER, M., "The schizophrenia of modern moral theories", in Virtue Ethics, R. Crisp and M. Slote (eds.), Oxford, Oxford University Press, 1997 [1976], p. 66-78.

TiBerius, V., Moral Psychology, London/New York, Routledge, 2015. 